\title{
Reducing Waste Disposal from Universiti Kebangsaan Malaysia Campus By 2-Bins Recycling System
}

\author{
Kian-ghee Tiew ${ }^{1}$, Kohei Watanabe ${ }^{2}$, Noor Ezlin Ahmad Basri ${ }^{1}$, Shahrom Md. Zain ${ }^{1} \&$ Hassan Basri ${ }^{1}$
}

\begin{abstract}
This is a study on the 2- bins recycling system at Universiti Kebangsaan Malaysia (UKM) year 2010 to reduce waste disposal at landfills. Fifty sets of 2-bins recycling system were allocated in the Faculty of Engineering and Built Environment, Universiti Kebangsaan Malaysia (UKM). The number of recyclable items found in the recycling and mixed waste bins served as dependent measurements. Results indicated that the recycling containers successfully recovered recyclable items by $49.5 \%$, but still a high proportion of recyclable items thrown into the mixed waste container which is $50.5 \%$ which indicates wrong bins usage. Awareness programs are required to increase rate of participation among students.
\end{abstract}

Keywords: Recycling, 2 bins system, campus

\section{INTRODUCTION}

66 Green Campus" is not a new concept in sustainability. University/campuses have done so many efforts to manage the

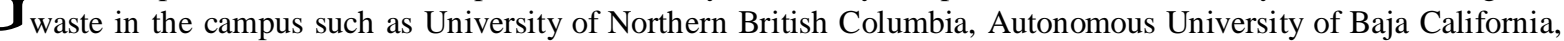
Massey University, Leeds University, and Cornell University [1, 2, 3, 4 \& 5]. Mostly, they are using the compost method to manage the organic waste, which gives the highest percentage of waste in the waste composition. In addition, recovery of recyclable items at source is an important way to educate the public and reducing the rate of waste disposal.

On $18^{\text {th }}$ December 2008, UKM has signed a Memorandum of Agreement (MoA) with Alam Flora Sdn Bhd to establish and to apply an Integrated Solid Waste Management at UKM [6]. The MoA open ways to the university in achieving its mission on Zero-Waste campus and to be a role model for other universities in Malaysia [6]. The analysis of waste composition of UKM and the total daily waste for UKM main campus (includes faculties, centres, institutes and dormitories) has been conducted for a year. Waste stream in UKM campus consists of $45.3 \%$ are recyclable items, $46.5 \%$ compostable items and $8.2 \%$ non-recyclable items [7]. Result shows that approximately $45.3 \%$ recyclable items could be recycled but in this study, those wastes were found to be dumped into landfill. Hence, separation at sources could be a good practice to recover the recyclable items.

Many researches has been done on people's values, beliefs, and attitudes in recycling compliance among public $[8,9,10$ \& 11]. Hence, the study of 2 bins recycling system is needed for UKM. The objective of this paper is to evaluate the effectiveness of 2 bins recycling system in recovering the recyclable items at source and, thus reducing the rate of waste disposal in UKM.

Kian-ghee Tiew. Department of Civil and Structural Engineering, Faculty of Engineering and Built Environmental, Universiti Kebangsaan Malaysia(corresponding author: 603-8921-7012; fax: 603-8921-6147; e-mail: tiew8585@yahoo.com).

Noor Ezlin Ahmad Basri, Shahrom Md. Zain \& Hassan Basri. Department of Civil and Structural Engineering, Faculty of Engineering and Built Environmental, Universiti Kebangsaan Malaysia.( E-mail: ezlin@vlsi.eng.ukm.my, smz@vlsi.eng.ukm.my \& drhb@vlsi.eng.ukm.my)

Kohei Watanabe. Institute for Environment and Development (LESTARI), Universiti Kebangsaan Malaysia and Teikyo University

UKM Bangi, 43600, Selangor Darul Ehsan, Malaysia.(kw10004@cam.ac.uk) 


\section{MAterials AND MethodS}

\section{Design and Materials}

Fifty waste stations were located throughout the Faculty of Engineering and Built Environment, FKAB. Ten waste stations were observed in the four-storey academic building, FKAB. Each station consists of two types of container: a commingled recycling bin and a mixed waste bin. The utility of these 2-bins system was used to test the attitudes and acceptance of students. The commingled recycling container had a general symbol of recycle without any notices (Figure 1 (a)). The swing cover lids are placed on top with "please no wet and dirty rubbish" tenor and the body of the container is orange colour (Figure 1 (b)). The mixed waste container is a standard garbage container available in market.

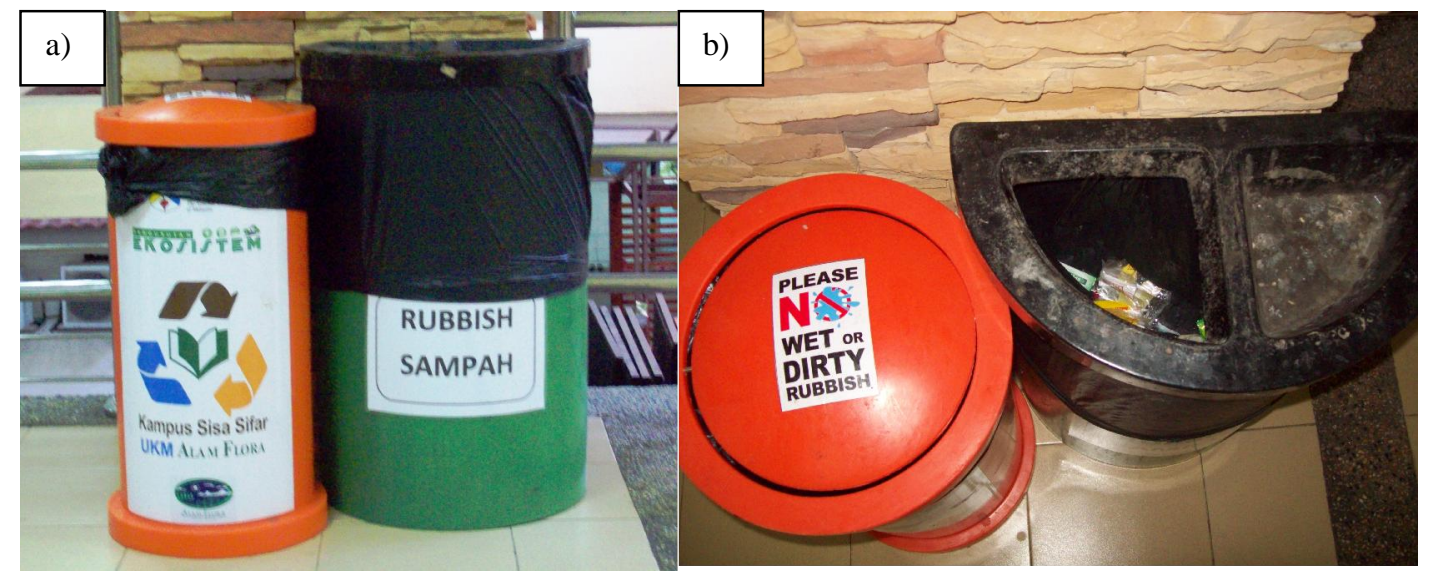

Figure 1 Image of 2-bins system

\section{Procedure}

Ten waste stations were randomly picked up for the segregation process. The segregation process was done during academic session and the items in the 2-bins recycling system were sorted into two main groups; recyclable and nonrecyclable materials [13]. Each category of the waste are weighed and recorded (Figure 2).

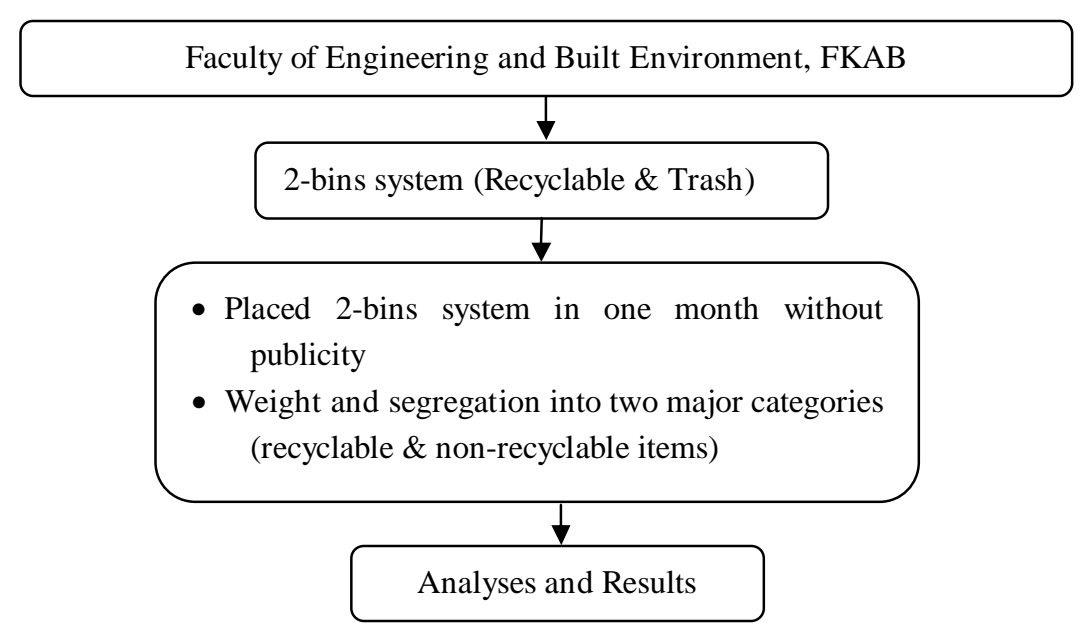

Figure 2 Flow chart of 2-bins system study 


\section{RESULTS AND DisCUSSIONS}

Table 1 shows the monthly waste generation in whole UKM campus, Bangi from $1^{\text {st }}$ July 2009 till $31^{\text {st }}$ July 2010 . The highest daily waste generation in UKM is 5.70 ton/day and the lowest is 3.02 ton/day. Average daily waste generated in UKM was high, compared to the University of Northern British Columbia, Autonomous University of Baja California, Massey University, Leeds University, and Cornell University due to high population rate in UKM which is 22,000 citizens [1, 2, 3, 4 \& 5]. Besides that, waste generated in UKM was affected by academic session, semester break season and the fasting month for Muslims. Hence, June 2010 had the lowest waste collection because of the semester break, while the peak season is in July 2009 and 2010, which is the new intake for an academic session.

Table 1 Waste Generation in UKM, 2009-2010

\begin{tabular}{lcc}
\hline \multicolumn{1}{c}{ Month } & Total Waste Disposal in Landfill (ton/month) & Average Daily Waste Disposal(ton/day) \\
\hline July-09 & 176.63 & 5.70 \\
August-09 & 156.64 & 5.05 \\
September-09 & 128.09 & 4.27 \\
October-09 & 169.85 & 5.48 \\
November-09 & 145.14 & 4.84 \\
December-09 & 112.22 & 3.62 \\
January-10 & 105.69 & 3.41 \\
February-10 & 145.60 & 5.20 \\
March-10 & 151.28 & 4.88 \\
April-10 & 150.5 & 5.02 \\
May-10 & 118.7 & 3.83 \\
June-10 & 90.5 & 3.02 \\
July-10 & 175.2 & 5.65 \\
\hline
\end{tabular}

The results in Table 2 and Table 3 showed that the 2-bins system still needed improvement at the faculty because $65.3 \%$ of the content in commingled recycle container is recyclable items while the others were non-recyclable items. There is still high amount of waste which is $34.7 \%$ due to non-recyclable items was being throwing into recycle bins. This shows that, publicity and awareness are needed to educate the public/staffs/students on the correct usage of recycling bins. Hence, in order to achieve a good practice, a good publicity and awareness programs are required. For mixed waste bins, the content was $58.7 \%$ non-recyclable items while the percentage for recyclable items is $41.3 \%$.

Table 2 Composition of Commingled Recycle Containers

\begin{tabular}{lcc}
\hline & Recycle Bin (Orange bin) & \\
\hline Recyclable Items & Amount(gram) & Percentage(weight/weight) \\
Papers & 283.8 & $31.1 \%$ \\
Tetrapak & 47.9 & $5.2 \%$ \\
Aluminum Can & 110 & $12.0 \%$ \\
Plastics & 155.3 & $17.0 \%$ \\
Non-Recyclable Items & Amount(gram) & Percentage(weight/weight) \\
Tissue Papers & 32.4 & $3.5 \%$ \\
Plastic Bag & 7.6 & $0.8 \%$ \\
Food Container (polystyrene) & 55.7 & $6.1 \%$ \\
Food Wrapper(Plastic packaging) & 39.1 & $4.3 \%$ \\
Food Waste & 60.2 & $6.6 \%$ \\
Miscellaneous & 121.9 & $13.3 \%$ \\
\multicolumn{1}{c}{ Total } & $\mathbf{9 1 3 . 9}$ & $\mathbf{1 0 0 . 0 \%}$ \\
\hline
\end{tabular}


UNIMAS e-Journal of Civil Engineering Vol. 2 (1) / March 2011

Table 3 Composition of Mixed Waste Containers

\begin{tabular}{lcc}
\hline & Mixed Waste Bin \\
\hline Non-Recyclable Items & Amount(gram) & Percentage(weight/weight) \\
Tissue Paper & 154.8 & $10.5 \%$ \\
Plastic Bag & 279 & $18.9 \%$ \\
Food Container & 81.6 & $5.5 \%$ \\
Food Wrapper & 19.1 & $1.3 \%$ \\
Food Waste & 239.5 & $16.2 \%$ \\
Misc & 92.3 & $6.3 \%$ \\
Recyclable Items & Amount(gram) & Percentage(weight/weight) \\
Glass & 8.8 & $0.6 \%$ \\
Papers & 179.6 & $12.2 \%$ \\
Tetrapak & 131 & $8.9 \%$ \\
Aluminum Can & 152.5 & $10.3 \%$ \\
Plastics & 127.2 & $8.6 \%$ \\
Metals & 0.9 & $0.1 \%$ \\
Others & 8.5 & $0.6 \%$ \\
& $\mathbf{1 4 7 4 . 8}$ & $\mathbf{1 0 0 . 0 \%}$ \\
\hline
\end{tabular}

The 2-bins recycling system is a useful yet simple facility to ensure the public/staff/students separate the recyclable items at source. If the public/staff/students were ignorant, the institutions must either appoint staffs to separate the recyclables items from source, or eliminate recycling programs altogether [12]. Publicity is needed due to high proportion of recyclable items was found in the mixed waste bins (Figure3). The 2-bins recycling system could be a good option to ensure students to separate the recyclable items because many past researches showed that the compliance is increasing when recycling bins are placed closer to users, and the physical features of the bins will also influence the recycling compliance [12]. Hence, for this study, colourful and special design of recycling bins is provided and placed in the areas which easily accessible/located by the users.

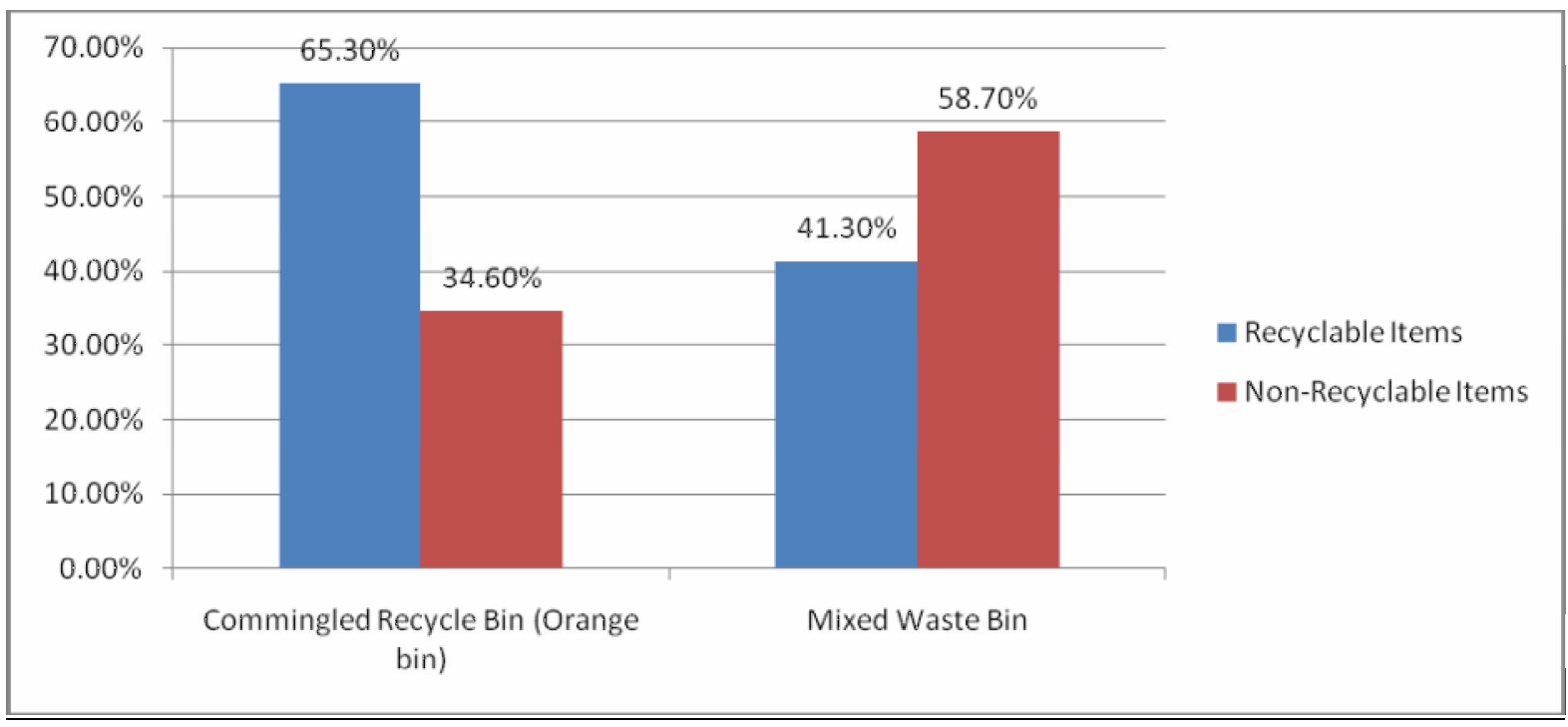

Figure 3 Summary of 2-bins system in FKAB, UKM 


\section{CONCLUSIONS}

The study has been successful in highlighting waste diversion from landfills at UKM and the results from the experiments of the 2-bins recycling system in FKAB indicated a sustainable method of reduce waste disposal in UKM. Recovery rate for the 2 bins system is $49.5 \%$ [recyclable items in orange bins $(597 \mathrm{gram}) /$ total recyclable items in the system (1205.5gram)] in the commingled recycling containers. Due to the lack of publicity of usage of this commingled recycle bins, some users still throw the recyclable items into mixed waste bins. If the 2-bins system could be implemented in UKM with good publicity of usage of commingled recycling bins, at least $49.5 \%$ recyclable items could be diverted rather than dumping into landfill. Future studies on the 2-bins system after the publicity and education programme will promote proenvironmental behaviors as an important step for UKM toward "Zero Waste Campus".

\section{ACKNOWLEDGMENT}

The authors are grateful for support this project which was carried out at the Universiti Kebangsaan Malaysia (under research grant UKM-PTS-007-2009 and UKM-GUP-PLW-08-13-052) with cooperation of Alam Flora Sdn Bhd (M).

\section{REFERENCES}

[1] Danielle P. Smyth, Arthur L. Fredeen, Annie L. Booth. (2010). Reducing solid waste in higher education: The first step towards 'greening' a university campus. Resources, Conservation and Recycling 54, 1007-1016.

[2] Carolina Armijo de Vega, Sara Ojeda Benítez, Ma. Elizabeth Ramírez Barreto. (2008). Solid waste characterization and recycling potential for a university campus. Waste Management, 28, S21-S26.

[3] I.G. Mason, A. Oberender, A.K. Brooking. (2004). Source separation and potential re-use of resource residuals at a university campus. Resources, Conservation and Recycling 40, 155-172.

[4] Stapleton, C., \& Fewtrell, L. (2001). Review of the Environmental Management Systems of the University of Leeds. Retrieved November 7, 2005. from the University of Leeds, Website: http://www.campus.leeds.ac.uk/creh_rvw.pdf

[5] Smithers, W. (2005). Cornell Sustainable Campus. Solid Waste Management. Retrieved October 9, 2005. from Cornell University, Website: http://www.sustainablecampus.cornell.edu/rrr-solid.htm

[6] Alam Flora (2009). Towards a clean environment: A proposal on sustainable and integrated solid waste management system for Universiti Kebangsaan Malaysia. Report fromAlam Flora.

[7] Kian-Ghee Tiew, Noor Ezlin Ahmad Basri, Irfana Kabir Ahmad and Hassan Basri. (2010). SOLID WASTE MANAGEMENT ISSUES AT UNIVERSITI KEBANGSAAN MALAYSIA. International Conference on Environmental Research and Technology (ICERT 2010). $705-709$.

[8] Barr, S. (2007). Factors influencing environmental attitudes and behaviors: A U.K. case study of household waste management. Environment and Behavior, 39, 435-473.

[9] Ewing, G. (2001). Altruistic, egoistic, and normative effects on curbside recycling. Environment and Behavior, 33, $733-764$.

[10] Guagnano, G. A., Stern, P. C., \& Dietz, T. (1995). Influences on attitude-behavior relationship: A natural experiment with curbside recycling. Environment and Behavior, 27, 699-718.

[11] Schultz, W. P., Nolan, J. M., Cialdini, R. B., Goldstein, N. J., \& Griskevicius, V. (2007). The constructive, destructive, and reconstructive power of social norms. Psychological Science, 18, 429-434.

[12] Sean Duffy \& Michelle Verges. (2009). It Matters a Hole Lot Perceptual Affordances of Waste Containers Influence Recycling Compliance. Environment and Behavior. Vol. 41, 5, 741-749.

[13] ASTM D 5231-92. 2003. Standard Test Method for Determination of the Composition of Unprocessed Municipal Solid Waste. 